\section{West Nile update - Preparing for summer 2004}

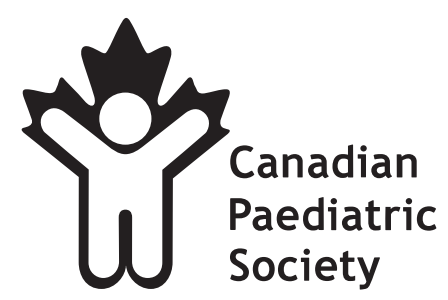

possible further analysis. If there is clinical or laboratory evidence suggestive of WNV infection in the newborn, further evaluation should include cranial computerized tomography, examination of cerebrospinal fluid, ophthalmological exam, complete blood count and liver function tests. Close continued follow-up should be ensured (5).

Protection against mosquito bites remains the most important preventive measure. Many parents have concerns about the use of mosquito repellents in young children. Repellents containing N,N-diethly-3-methylbenzamide (DEET) are most studied and are reliable and safe if used appropriately. Experience with other products is limited. A repellent containing p-methane 3,8,diol, a derivative of eucalyptus, protects for up to two hours and may be used twice a day but is not recommended for children less than three years of age. Soybean oil based products are effective for $1 \mathrm{~h}$ to $3.5 \mathrm{~h}$ and are registered for use as repellents in Canada but are not readily available at present. As the active ingredient is edible grade soybean oil, these are expected to be safe for the use in young children. Citronella and lavender products provide a shorter duration of protection and are currently being re-evaluated by Health Canada for safety and effectiveness. These are not recommended for children less than two years old. While plant-derived products are often thought of as safe, plant oils may be potent skin sensitisers. Whichever product is chosen, it should carry a Health Canada Pest Control Products Act registration number and be labelled as an insect repellent for use on humans $(1,6)$.

For information about WNV infection and preventive measures, please refer to the Paediatric Infectious Disease Note published in 2003 (7). The current note is an update and should be considered as an addendum to the previous one.

\section{REFERENCES}

1. Health Canada. West Nile Virus.

<www.hc-sc.gc.ca/english/westnile/index.html> (Version current at May 13, 2004).

2. Weinstein M. Atypical West Nile infection in a child. Pediatr Infect Dis J 2003;22:842-4.

3. Kumar D, Prasad GV, Zaltzman J, Levy GA, Humar A. Communityacquired West Nile virus infection in solid-organ transplant recipients. Transplantation 2004;77:399-402 Histopathology examination should be performed on the placenta and specimens of placenta and cord frozen for 
4. Gea-Banacloche J, Johnson RT, Bagic A, Butman JA, Murray PR, Agrawal AG. West Nile virus: Pathogenesis and therapeutic options. Ann Intern Med 2004;140:545-53.

5. Centers for Disease Control and Prevention. Interim guidelines for the evaluation of infants born to mothers infected with West Nile virus during pregnancy. MMWR Morb Mortal Wkly Rep 2004;53:154-7. <www.cdc.gov/ncidod/dvbid/westnile/ congenitalinterimguidelines.htm $>$ (Version current at May 13, 2004).
6. Health Canada. Pest Management Regulatory Agency: Mosquito Control. <www.hc-sc.gc.ca/pmra-arla/english/mosquito/ mosquito-e.html> (Version current at May 13, 2004).

7. Canadian Paediatric Society, Infectious Diseases and Immunization Committee. West Nile virus - Mosquitoes no longer just an annoyance! Paediatr Child Health 2003;8:267-70.

<www.cps.ca/english/statements/ID/PIDNoteWestNile.pdf>

(Version current at May 13, 2004).

\section{CANADIAN PAEDIATRIC SOCIETY, INFECTIOUS DISEASES AND IMMUNIZATION COMMITTEE (2003-2004)}

Members: Drs Upton Allen, The Hospital for Sick Children, Toronto, Ontario; H Dele Davies, East Lansing, Michigan, USA; Simon Richard Dobson, BC's Children Hospital, Vancouver, British Columbia; Joanne Embree, The University of Manitoba, Winnipeg, Manitoba (Chair); Joanne Langley, IWK Health Centre, Halifax, Nova Scotia; Dorothy Moore, Montreal Children's Hospital, Montreal, Quebec; Gary Pekeles, Montreal Children's Hospital, Montreal, Quebec (Board Representative)

Consultant: Drs Gilles Delage, Héma Québec, Saint-Laurent, Québec Noni MacDonald, Dalhousie University, Halifax, Nova Scotia

Liaisons: Drs Scott Halperin, IWK Health Centre, Halifax, Nova Scotia (IMPACT); Susan King, The Hospital for Sick Children, Toronto, Ontario (Canadian Paediatrics AIDS Research Group); Monica Naus, BC Centre for Disease Control, Vancouver, British Columbia; Larry Pickering, Centre for Disease Control and Prevention, Atlanta Georgia, USA (American Academy of Pediatrics, Committee on Infectious Diseases) Principal author: Dorothy Moore, Montreal Children's Hospital, Montreal, Quebec

The recommendations in this statement do not indicate an exclusive course of treatment or procedure to be followed. Variations, taking into account individual circumstances, may be appropriate. This article also appears in Paediatr Child Health 2004;9(5):301-302.

\section{ERRATUM}

Canadian Paediatric Society, Infectious Diseases and Immunization Committee. Routine immunization schedule: Update 2004. Can J Inf Dis 2004;15(1):17-20.

The Canadian Paediatric Society (CPS) would like to apologize for any errors or omissions found in the January/February 2004 Paediatric Infectious Disease Note entitled "Routine immunization schedule: Update 2004." The editors have found that the charts did not accurately report all provincial vaccination programs. In addition, several provinces have added vaccine programs to their respective routine immunization schedules since January. Therefore, the charts have been republished on the CPS Web site at <http://www.cps.ca/http://www.cps.ca/english/statements/ID/PIDNoteImmunization.htm> and will be updated regularly with new data as it becomes available.

We apologize for any inconvenience this may have caused. 


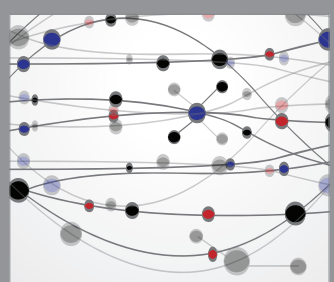

The Scientific World Journal
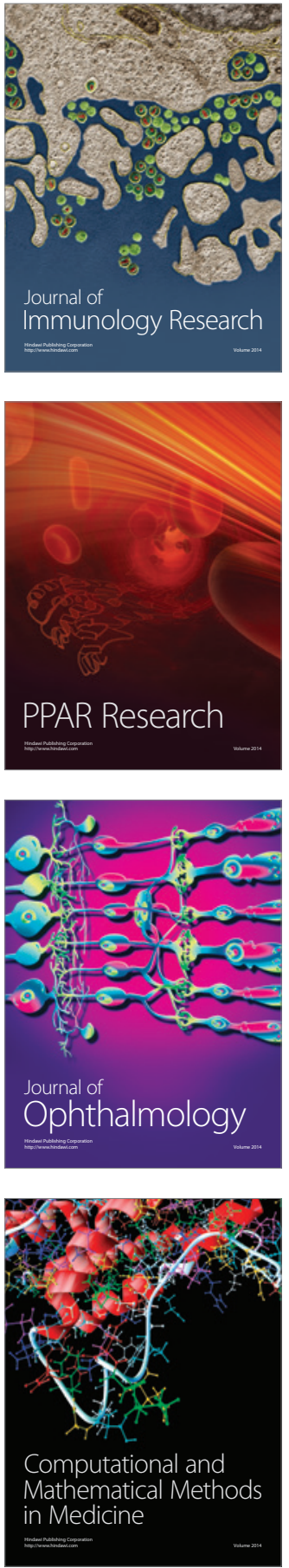

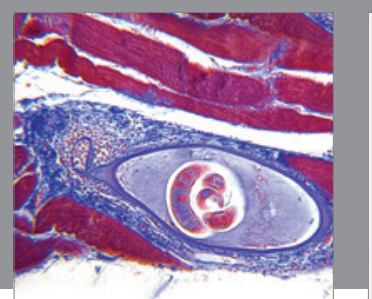

Gastroenterology Research and Practice

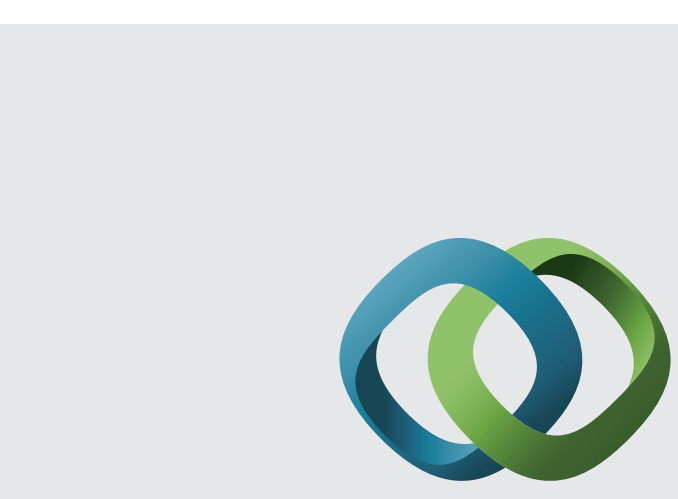

\section{Hindawi}

Submit your manuscripts at

http://www.hindawi.com
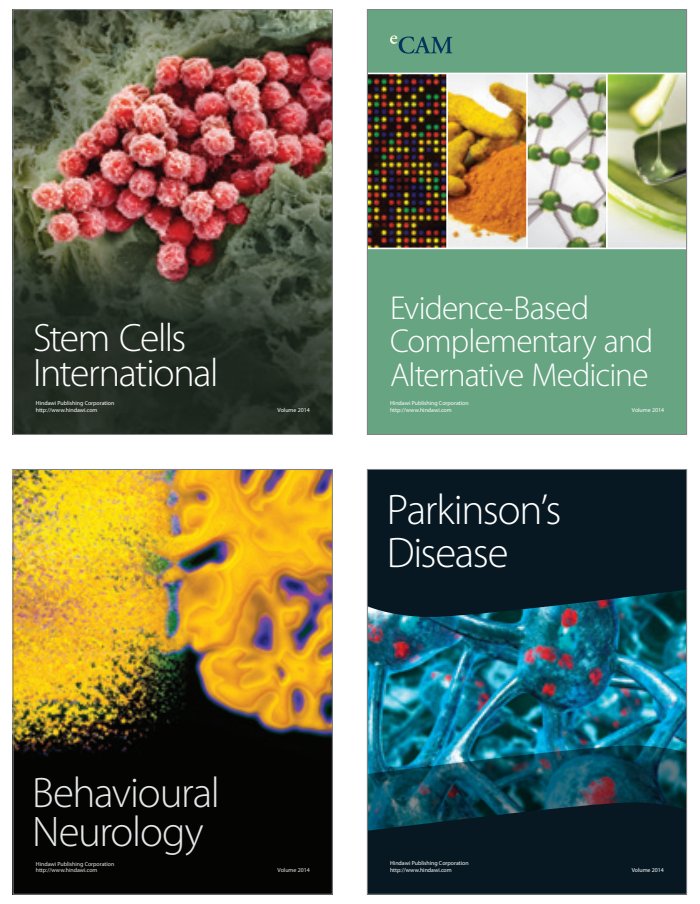
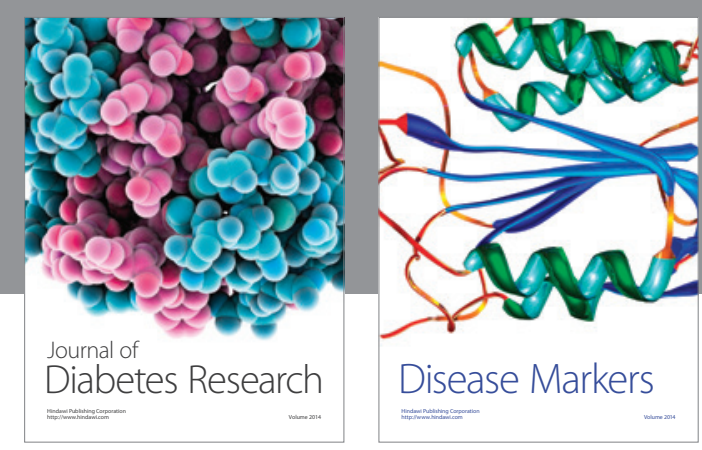

Disease Markers
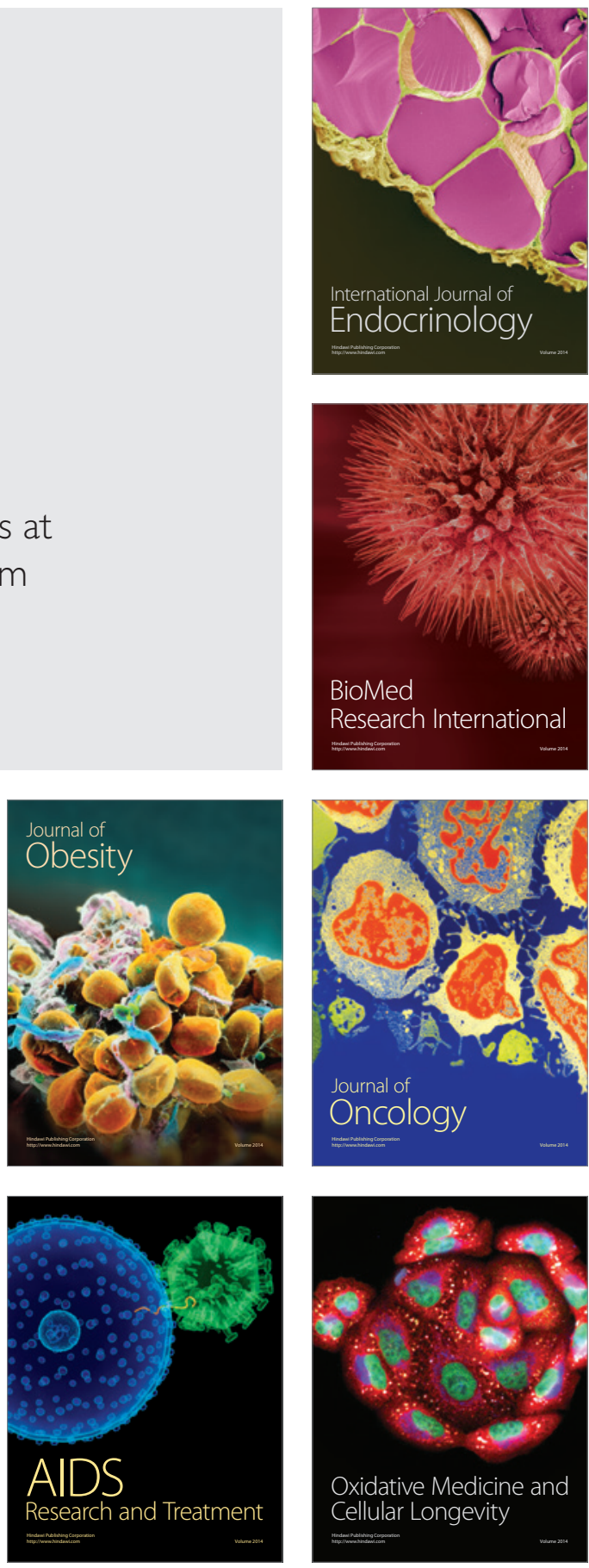